\title{
Sciendo
}

DOI 10.2478/afepuc-2021-0018

(C) 2021 Author(s). This is an open access article licensed under the Creative Commons

Attribution-NonCommercial-NoDerivatives 4.0 International

(https://creativecommons.org/licenses/by-nc-nd/4.0/)

\section{MONTHS OF BALANCE TRAINING DECREASES ANKLE-JOINT INJURY FREQUENCY IN YOUNG GIRL BASKETBALL PLAYERS}

\author{
T. Nováková, J. Tufano, A. Veseláková \\ Charles University in Prague, Faculty of Physical Education and Sport, Department of Physiotherapy, Czech \\ Republic

\begin{abstract}
Summary: Aim: Balance training can help reduce the frequency of ankle joint injuries in adults, but data on young girls is relatively scant. Methods: Out of 91 female basketball players (7-16 years), 40 players were assigned to an experimental balance training group, and 51 players were assigned to a control group. Both groups performed their typical basketball training but the experimental group performed additional balance-focused exercises during the warm-up of their basketball training sessions. Results: A total of 47 girls $(52 \%)$ reported at least one ankle joint injury in their entire basketball history $(52.5 \%$ in the experimental, $50.9 \%$ in the control group). There was a positive correlation between the number of ankle joint injuries and age before the experiment $(r=0.34, p<0.001)$. During the 12-month study period, girls who participated in balance training suffered significantly fewer ankle joint injuries than the control group $(\chi 2=3.8423, \mathrm{df}=1, \mathrm{p}$-value $<0.05)$. Increased risk for ankle joint injury in the future was confirmed according to logistic regression for girls with previous ankle joint injury in history (4.33 times) and girls who did not participate in the balance training program (3.97 times). Conclusions: A progressive, barefoot balance training program that is simple and short enough to be performed during normal warmups can reduce the likelihood of suffering an ankle joint injury in young girls basketball players, which may be useful for athletes in other sports as well.
\end{abstract}

Key Words: ankle sprain, female, instability, school age players, sensorimotor exercises.

\section{Introduction}

From 1997 to 2007, it was reported that over 4 million injuries occurred during basketball games in players under 20 years old in the United States (Randazzo et al. 2010), 
making basketball one of the five most common settings for sport injuries in young athletes (Schwebel \& Brezausek 2014). Within basketball, epidemiological studies repeatedly point to a high percentage of ankle injuries (Borowski et al. 2008; Cumps et al. 2007), specifically ankle joint sprains (Messina et al. 1999; Colliander et al. 1986). Such injuries occur in both genders and across all levels of competition (Leanderson et al. 1993), but a higher frequency has been documented in females (Agel et al. 2007; Deitch et al. 2006; Dick et al. 2007; Drakos et al. 2010; Waterman et al. 2010). Unfortunately, when a basketball player suffers an ankle joint injurie (AJI), frequent relapses are not uncommon, which can deactivate a player for the remainder of the season and possibly contribute to the development of chronic ankle joint instability (Postle et al. 2012; van Rijn et al. 2008; Verhagen \& Bay 2010). Although chronic ankle joint instability is never desired, developing such a condition at a young age could be detrimental to a child's future.

In adult athletes, the treatment and prevention of AJI and their relapse is well documented, but studies investigating the same in youth players are rare. In the event of an AJI, a balance training program implemented throughout a sports season can reduce the rate of ankle sprains (McGuine \& Keene 2006) and can increase functional ankle joint stability (Kaminski et al. 2013; McGuine \& Keene 2006; Sandlin et al. 2017; Zech et al. 2010). Therefore, although a balance training program as a primary intervention can be useful in preventing sprains in athletes with healthy ankles, but it must also be part of secondary prevention if an AJI has already occurred in the past. Specifically, performing balance training "barefoot" is recommended due to increased proprioceptive facilitation in the foot and ankle area, thereby increasing the efficiency of sensorimotor training (Sefton et al. 2011; Freeman et al. 1965; Page 2006; Frank et al. 2009; Ghram et al. 2017). However, few studies state whether balance training with proprioceptive functions can reduce the risk of injury while reducing the severity of subsequent ankle sprains, and such data is lacking in young girls. Therefore, the aim of our study was to first, provide an account of the incidence rate and prevalence period of AJIs in female basketball players aged from 7 to 16 years old. Then, we examined the effectiveness of regular barefoot balance training for reducing the occurrence of AJIs throughout an entire calendar year. We hypothesized that performing a progressive barefoot balance training program twice a week would reduce the number of AJIs in young female basketball players compared to players who did not perform the barefoot balance training program. 


\section{Methods}

The main objectives of this research were to determine the number of AJIs in girl basketball players aged from 7 to 16 years old and then to evaluate the effectiveness of balance exercises integrated into the regular basketball training sessions of the experimental group. A total of 91 girls ( 7 to 16 years old) participated in this study. In an attempt to control for various factors including playing level, experience, age, cultural playing styles, and the like, all 91 girls were recruited from three basketball clubs with teams that spanned across the 7- to 16-year-old categories, played in the same competition league (i.e. regional level teams), and trained 2 to 3 times a week. Additionally, all of the girls had been playing basketball for at least two years prior to the beginning of the study according to the age category. The study was approved by the university's institutional review board (n. 048/2015), and as all participants were under 18 years old, both parental and child consent were obtained.

First, AJI frequency data (AJI_PRE) were collected from all 91 girls via written questionnaires that were completed with the assistance of their parents after volunteering for the study but before the start of the 12-month study period. Next, the girls were assigned to either an experimental group $(n=40)$ or a control group $(n=51)$. In either case, all of the girls on a single team were assigned to the same group so that there were not members of the experimental group and control group on the same team. Although this decision meant that the girls were not randomized between the groups, we did not want girls in the control group to see what their teammates were doing before practice (possibly then doing their own exercises at home despite being told not to). During the 12-month study period, both groups performed their normal basketball training, but the experimental group (BAL) performed additional barefoot balance training twice a week before practice in the beginning of their basketball training session (i.e. twice a week from 2-3 basketball trainings). Girls in the control group (CON) did not perform additional balance training. After 12 months, surveys were administered again to determine the effect of balance training on the frequency of AJI (AJI_POST).

\section{Personal sport injury history data}

The quantity and frequency of AJIs were determined using a hard-copy survey containing 12 questions (personal sport history and injury data), both closed and open-ended questions. Specifically, questions focused on whether the athlete had suffered an AJI in in their basketball history (AJI_PRE), the number of recurrent AJIs, the exact type of injury as diagnosed by a medical doctor, and other questions that were not related to the data within the 
present study. Baseline surveys were administered during February, at the end of the competitive season. Parents were asked to prepare the medical documentation of any and all previous AJI-related injuries ahead of time. Then, the girls completed the surveys during practice time alongside their parents, and the surveys were immediately returned to their coach who then gave the hard copies to the researchers. At this time, the players and their parents were asked to register all of the injuries suffered in the next 12 months, during the study period. After 12 months, the same survey process was repeated, also in February, from which the postintervention data were collected (AJI_POST).

\section{2-Month Study Period}

During the 12-month study period, BAL players completed supervised balance exercises during their twice weekly basketball practices (the frequency of twice a week was maintained even though basketball training was conducted three times a week). After the team's warm-up, the girls removed their shoes and socks and performed the balance exercises barefoot, lasting approximately 10 to 15 minutes. The elements of the balance exercises were based on sensorimotor exercises according to Freeman (Page 2006, Rohde 2012, Sefton et al. 2011, Freeman et al. 1965), but were modified according to space and equipment availability. In the preparatory phase, the emphasis was on achieving the full range of motion of the soles of the feet and ankles, active movements, and stretching (i.e. proprioceptive neuromuscular facilitation). In the next stage, exercises emphasized position awareness and movement control with the eyes closed (i.e. somatognosis and kinesthesia) by adjusting the position of the feet and ankles to maintain the center of pressure with the body in different positions. In the next phase, there was an emphasis on performing exercises on balance aids while focusing on the proper alignment of the lower limbs and trunk. Throughout the 12-month study period, the time devoted to the various stages and the intensity of the exercises were progressively adjusted (Table 1). Progress to higher levels of balance training was dependent on the quality of performance in each level and individualized by a supervisor (difference was just in weeks), and finally all girls reached the final level.

Table 1

The balance training plan 


\begin{tabular}{|c|c|c|c|c|c|c|c|}
\hline & \multirow{2}{*}{$\begin{array}{l}\text { Balance } \\
\text { exercise } \\
\text { focus } \\
\end{array}$} & \multirow{2}{*}{ Focused area } & \multirow{2}{*}{ Examples of specific exercises } & \multicolumn{4}{|c|}{ Approximate time in minutes } \\
\hline & & & & $\begin{array}{c}\text { Months } \\
0-2\end{array}$ & $\begin{array}{c}\text { Months } \\
3-4\end{array}$ & $\begin{array}{c}\text { Months } \\
5-6\end{array}$ & $\begin{array}{c}\text { Months } \\
7-12\end{array}$ \\
\hline \multirow[t]{3}{*}{$\begin{array}{l}\text { Preparatory } \\
\text { phase }\end{array}$} & $\begin{array}{l}\text { Increase } \\
\text { passive and } \\
\text { active ankle } \\
\text { range of } \\
\text { motion }\end{array}$ & $\begin{array}{l}\text { The extrinsic } \\
\text { muscles } \\
\text { mainly } \\
\text { responsible for } \\
\text { eversion, } \\
\text { inversion, } \\
\text { plantarflexion, } \\
\text { and } \\
\text { dorsiflexion of } \\
\text { the foot. }\end{array}$ & $\begin{array}{l}\text { Passive stretching of triceps } \\
\text { surea, muscles participate } \\
\text { on dorsiflexion and } \\
\text { in inversion and eversion, } \\
\text { Active movements to } \\
\text { inversion and eversion, } \\
\text { gradually using elastic } \\
\text { resistance bands and } \\
\text { increasing difficulty from } \\
\text { simple positions to positions } \\
\text { requiring high postural } \\
\text { stabilization functions. }\end{array}$ & \multirow{3}{*}{$6^{\prime}$} & \multirow{3}{*}{$5^{\prime}$} & \multirow{3}{*}{$4^{\prime}$} & \multirow{3}{*}{$2^{\prime}$} \\
\hline & $\begin{array}{l}\text { Increase } \\
\text { mobility in } \\
\text { the sole of } \\
\text { the foot }\end{array}$ & $\begin{array}{l}\text { The intrinsic } \\
\text { muscles } \\
\text { responsible for } \\
\text { the fine motor } \\
\text { actions of the } \\
\text { foot, for } \\
\text { example } \\
\text { movement of } \\
\text { individual } \\
\text { digits }\end{array}$ & $\begin{array}{l}\text { Plantar aponeurosis stretching, } \\
\text { passive increasing of ROM in } \\
\text { abduction of big toe. } \\
\text { Using e.g. treads with a } \\
\text { holding time on a tennis ball } \\
\text { to an increased mobility of } \\
\text { soles into plantar flexion. }\end{array}$ & & & & \\
\hline & $\begin{array}{l}\text { Facilitate } \\
\text { propriocepti } \\
\text { on of ankle } \\
\text { and foot area }\end{array}$ & $\begin{array}{l}\text { All joints, } \\
\text { ligaments and } \\
\text { muscles in the } \\
\text { ankle joint and } \\
\text { foot area. }\end{array}$ & $\begin{array}{l}\text { Stretching, increased } \\
\text { segmentally localized activity } \\
\text { and targeted relaxation of } \\
\text { muscles and increased joint } \\
\text { play in all previous exercises } \\
\text { are a prerequisite for } \\
\text { facilitating proprioception. }\end{array}$ & & & & \\
\hline \multirow[t]{3}{*}{$\begin{array}{l}\text { Switching } \\
\text { from } \\
\text { awareness to } \\
\text { automatic } \\
\text { control } \\
\text { phase }\end{array}$} & $\begin{array}{l}\text { Improve } \\
\text { kinaesthetic } \\
\text { awareness }\end{array}$ & $\begin{array}{l}\text { The awareness } \\
\text { of the position } \\
\text { and movement } \\
\text { in ankle and } \\
\text { foot area. }\end{array}$ & $\begin{array}{l}\text { Exercise focused on vision- } \\
\text { controlled change of position } \\
\text { in the ankles, feet and toes. } \\
\text { Games based on the } \\
\text { manipulation of objects using } \\
\text { foot and toes. Walking on } \\
\text { different surfaces and reliefs } \\
\text { of the pad. }\end{array}$ & \multirow{3}{*}{$6^{\prime}$} & \multirow{3}{*}{$5^{\prime}$} & \multirow{3}{*}{$1^{\prime}$} & \multirow{3}{*}{$1^{\prime}$} \\
\hline & $\begin{array}{l}\text { Improve } \\
\text { kinaesthetic } \\
\text { awareness } \\
\text { without } \\
\text { visual } \\
\text { stimuli }\end{array}$ & $\begin{array}{l}\text { The awareness } \\
\text { of the position } \\
\text { and movement } \\
\text { in ankle and } \\
\text { foot area } \\
\text { without visual } \\
\text { control. }\end{array}$ & $\begin{array}{l}\text { Exercises with an emphasis on } \\
\text { awareness of the position and } \\
\text { movement of the area without } \\
\text { visual control. All previous } \\
\text { exercises without visual } \\
\text { control performance. }\end{array}$ & & & & \\
\hline & $\begin{array}{l}\text { Improve } \\
\text { kinaesthetic } \\
\text { awareness } \\
\text { without } \\
\text { visual }\end{array}$ & $\begin{array}{l}\text { Load soles } \\
\text { body weight at } \\
\text { different } \\
\text { positions on a } \\
\text { solid support }\end{array}$ & $\begin{array}{l}\text { Stepping and lunges in all } \\
\text { directions with controlled } \\
\text { straightening of the trunk and } \\
\text { axial adjustment entire lower } \\
\text { extremity (avoiding internal }\end{array}$ & & & & \\
\hline
\end{tabular}




\begin{tabular}{|c|c|c|c|c|c|c|c|}
\hline & stimuli & & $\begin{array}{l}\text { rotation of the hip and } \\
\text { valgosity in knee and ankle). } \\
\text { One leg stands. All exercises } \\
\text { can be more difficult with } \\
\text { another task (throwing and } \\
\text { catching the ball). }\end{array}$ & & & & \\
\hline \multirow[t]{2}{*}{$\begin{array}{l}\text { Specific } \\
\text { balance } \\
\text { training } \\
\text { phase }\end{array}$} & $\begin{array}{l}\text { Improve } \\
\text { static } \\
\text { balance, } \\
\text { placing } \\
\text { focus on } \\
\text { aligning the } \\
\text { lower limbs } \\
\text { and trunk on } \\
\text { balance } \\
\text { surface }\end{array}$ & $\begin{array}{l}\text { Controlling } \\
\text { the position } \\
\text { and } \\
\text { distribution of } \\
\text { foot load by } \\
\text { weight of the } \\
\text { body in } \\
\text { different } \\
\text { positions on } \\
\text { balance pads } \\
\text { and aids }\end{array}$ & $\begin{array}{l}\text { Exercise in stand or in } \\
\text { stepping on balance pad. One } \\
\text { leg stands. All exercises can } \\
\text { be more difficult with another } \\
\text { task (throwing and catching } \\
\text { the ball). }\end{array}$ & \multirow[t]{2}{*}{$3^{\prime}$} & \multirow[t]{2}{*}{$5^{\prime}$} & \multirow[t]{2}{*}{$10^{\prime}$} & \multirow[t]{2}{*}{12} \\
\hline & $\begin{array}{l}\text { Improve } \\
\text { dynamic } \\
\text { balance, } \\
\text { placing } \\
\text { focus on } \\
\text { aligning the } \\
\text { lower limbs } \\
\text { and trunk on } \\
\text { balance aids }\end{array}$ & $\begin{array}{l}\text { exercises on } \\
\text { balance aids } \\
\text { with an } \\
\text { emphasis on } \\
\text { the alignment } \\
\text { of the lower } \\
\text { limbs and } \\
\text { trunk }\end{array}$ & $\begin{array}{l}\text { Exercise based on movement } \\
\text { task on balance aid. Exercises } \\
\text { with balls, jumps, multitask in } \\
\text { movement, walk on balance } \\
\text { walkway. }\end{array}$ & & & & \\
\hline
\end{tabular}

\section{$\underline{\text { Statistical analysis }}$}

All data were analysed using statistical software R. We examined the relationship between the binary quantities AJI_POST and belonging to a group (undergoing balance training). We evaluated it using the Chi square test with Yates' continuity correction for significance of number of AJI_POST in both groups. When modeling this relationship, we decided to adjust for the presence of other potential factors such as age and an indicator of previous injury (AJI_PRE).

To this end, a logistic regression model was used, which models the conditional probability of injury (within 12 months) given the age of the player (at the beginning of the experiment) ranging from 7 to 16 years, previous experience of AJI_PRE ( $0=$ none, $1=$ at least one) and their assigned group (BAL for experimental balance group and CON for the control group). 


\section{Results}

\section{Entire basketball history}

In their entire basketball history, 47 girls $(51.6 \%)$ reported having at least one AJI. Older players had been at risk for longer and therefore had more numbers of previous injuries (AJI_PRE), as supported by a statically significant positive correlation between age and number of AJIs $(r=0.34, p<.001)$. The number of AJIs varied from one to six with a maximum of four AJIs on the same ankle joint, the medical diagnoses of which (in AJI_PRE) were described as a distortion in $87.2 \%$. Then, in the occurrence of about $2 \%$ of all AJI_PRE, there was a distortion with calcaneal fracture, a distortion with malleolus lateralis fracture, a distortion with malleolus lateralis fracture and contusion of surrounding muscles, a distortion and contusion of surrounding muscles, a malleolus lateralis fracture, and a luxation of the ankle joint. Only one player (16 years old) mentioned that surgery was needed for ankle joint luxation; the rest of the injured girls were treated in a conservative way (rest or fixation).

\section{2-month study period}

According to the results in Table 2, 21 girls (52.5\%) from BAL had suffered at AJI_PRE at some point in their history before the experiment.

\section{Table 2}

Ankle joint injuries related to age categories and basketball teams before (AJI_PRE) and after(AJI_POST) the experiment in balance training group (BAL) and control group (CON)

\begin{tabular}{|c|c|c|c|c|c|c|c|}
\hline & \multirow{2}{*}{$\begin{array}{c}\text { Total } \\
\text { number of } \\
\text { players }\end{array}$} & \multicolumn{4}{|c|}{$\begin{array}{c}\text { Number of injured players (n=47) } \\
\text { AJI_PRE }\end{array}$} & \multicolumn{3}{c|}{ Number of injured players (n=16) } \\
\hline AGE & $\mathrm{n}=91$ & total & BAL & CON & total & BAL & CON \\
\hline 7 & 2 & 0 & 0 & 0 & 0 & 0 & 0 \\
\hline 8 & 7 & 0 & 0 & 0 & 0 & 0 & 0 \\
\hline 9 & 6 & 1 & 1 & 0 & 1 & 0 & 1 \\
\hline 10 & 14 & 7 & 4 & 3 & 1 & 0 & 1 \\
\hline 11 & 14 & 8 & 5 & 3 & 1 & 1 & 0 \\
\hline 12 & 12 & 5 & 4 & 1 & 2 & 1 & 1 \\
\hline 13 & 6 & 3 & 2 & 1 & 2 & 0 & 2 \\
\hline 14 & 7 & 4 & 1 & 3 & 2 & 0 & 2 \\
\hline 15 & 10 & 9 & 1 & 8 & 3 & 0 & 3 \\
\hline 16 & 13 & 10 & 3 & 7 & 4 & 1 & 3 \\
\hline & 91 & 47 & 21 & 26 & 16 & 3 & 13 \\
\hline
\end{tabular}


However, during the 12-month intervention, only 3 girls $(7.5 \%)$ from BAL suffered an AJI_POST. In CON, 26 girls (50.9\%) had suffered at AJI at some point in their history before the experiment, and during the 12-month intervention, 13 girls $(25.5 \%)$ from CON suffered an AJI_POST. The girls from BAL suffered significantly fewer AJI_POST than CON group in the 12-month study period (Table 3 ) according to the Pearson's Chi-squared test $(\chi 2=3.8423$, $\mathrm{df}=$ $1, \mathrm{p}=0.049)$.

Table 3

The girls from BAL had suffered significantly fewer AJI than CON group in 12-month study period according to the Pearson's Chi-squared test $\left(\chi^{2}=3.8423, d f=1, p\right.$-value $\left.=0.04997\right)$ - test the independence of two categorical variables

\begin{tabular}{|l|l|l|l|}
\hline & & BAL & CON \\
\hline AJI_POST in 12 months & 0 & 37 & 38 \\
\hline AJI_POST in 12 months & 1 & 3 & 13 \\
\hline
\end{tabular}

Although, becoming one year older increases the risk of suffering an AJI_POST by $14 \%$, this increase was not statistically significant $(\mathrm{p}>0.05)$ and, therefore, age (one year older) cannot be considered to be a significant risk factor. Girls in the CON group had almost 4-times (3.97) higher risk of AJI_POST than if they were in the BAL group $(p \leq 0.05)$. Girls who had already experienced an AJI_PRE in the past had more than 4-times (4.33) higher risk of an AJI_POST (Table 4).

Table 4

The logistic regression model which models the probability of injury (within the 12-month study period) to account for the age and the previous experience with the basketball player's injury

\begin{tabular}{|c|c|c|c|c|}
\hline Coefficients & Estimate & Std. Error & $z$ value & $\operatorname{Pr}(>|z|)$ \\
\hline$\beta_{0}$ intercept & -5.1156 & 1.6994 & -3.010 & $0.00261 *$ \\
\hline$\beta_{1}$ age & 0.1342 & 0.1382 & 0.971 & 0.33174 \\
\hline$\beta_{2}$ group CON & 1.3778 & 0.7294 & 1.889 & 0.05891 \\
\hline $\begin{array}{ll}\beta_{3} & \text { pre_AJI }\end{array}$ & 1.4667 & 0.7574 & 1.937 & 0.05280 \\
\hline & Df & Wald & $\mathbf{P}(\mathbf{W}>\mathbf{w})$ & LRT P(LR > lr $)$ \\
\hline age & 1 & 0.942088 & 0.9529251 & 0.32897584 \\
\hline group & 1 & 3.567857 & 4.1108966 & 0.04260777 \\
\hline pre_AJI & 1 & 3.750083 & 4.2959585 & 0.03820306 \\
\hline
\end{tabular}


Combining the significant results we can claim that a basketball player avoiding balance training with previous ankle injury has about 17-times (17.19) higher risk of (another) AJI than a basketball player practicing the balance training with no prior injury of the same age. From the baseline survey, it was found that out of 91 girls, 51\% had previously suffered an AJI_PRE at some point, but more importantly and as hypothesized, the balance-training program seemed to have a positive effect on reducing the occurrence of AJIs during the 12-month study period, with fewer BAL girls suffering an AJI_POST $(n=3)$ compared to CON girls $(n=13)$. Together, these data highlight the importance of implementing balance-specific training at a young age to serve as a type of AJI countermeasure in young female basketball players.

\section{Discussion}

Reducing the risk of injuries should be one of the main aims of all coaches working with children, especially where repeated injuries may prematurely terminate a child's sports career or active lifestyle. Fortunately, basketball-specific injury prevention programs can significantly reduce the incidence of ankle sprains in basketball (Kaminski et al. 2013; McGuine \& Keene 2006; Sandlin et al. 2017; Zech et al. 2010) or volleyball athletes (Farzami \& Anbarian 2020), and prevention programs that emphasize proprioception and balance training can be successful in reducing AJIs in other high-risk multidirectional sports (Taylor et al. 2015). Balance exercises are often used to increase the muscle strength, coordination, postural control, and mobility of individual structures (Zech et al. 2010; McGuine \& Keene 2006; Sierra-Guzman et al. 2018; Melam et al. 2018; Farzami \& Anbarian 2020), and according to one systematic survey of postural management and acute lateral instability (McKeon \& Hertel 2008), balance exercises may be more beneficial for patients who have a history of ankle-rupture sprain and who have been practicing for 2 years. Therefore, the reduction in AJI_POST in the BAL group of the present study agrees with their findings.

Considering the ages of the girls, the percentage of injuries among the 10- to 14-yearolds ranged from $41.7 \%$ to $57.1 \%$, whereas $90 \%$ of 15 -year-olds were injured, and $69 \%$ of 16-year-olds. These values exceed those of other studies that were conducted in adults showing that injuries occurred in $20.8 \%$ out of 204 players (Kofotolis \& Kellis 2007) and $24.7 \%$ of professional players regardless of gender (Fong et al. 2007), as was expected (Doherty et al. 2014). As for the girls in the present study, an increase in the number of girls injured around 15 years old could be partly associated with how the game is played at older ages, with more physical contacts during the game, a greater total training time, and more matches as all teams 
at this age have training at least 3 times a week and some girls start playing simultaneously with other teams. Another possible explanation could be a relatively quick change in body mass ratios (Kofotolis \& Kellis 2007; Randazzo et al. 2010), which the girls may not be prepared for, decreasing their self-control and kinesthetic awareness. However, these hypotheses remain purely speculative, as the data from the current study cannot confirm or refute these claims, indicating that future research should delve deeper into these possible relationships.

In addition, attention was focused on the number of recurrent AJI, with 23 girls reporting two or more injuries in their basketball history (48.9 \% of all the injured girls). In one metaanalysis (Postle et al. 2012), it was reported that the AJI sprain recurrence rate in active athletes can be upwards up 70 to $80 \%$, which is a problem that has received a lot of attention within the literature (Hung 2015; Kaminski et al. 2013; van Rijn et al. 2008; Sandlin et al. 2017; Cumps et al. 2007). The recurrence rate of ankle sprains can be affected by the severity of the first AJI sprain, the use of passive support, the involvement of balancing exercises, a quick return to play, or the time played during basketball. In the present study, there was a positive correlation between the number of AJI and age before experiment. The number of AJI_PRE varied from one to six with a maximum of four AJIs on the same ankle joint. Such a high number of repeated AJIs (i.e. recurrent ankle sprains) may partially be explained by the questionnaire used in the present study where the presence of sprains was evaluated only on the basis of an inquiry, where the significance of the sprain was explained and the basic clinical manifestations described. Due to the nature of the research, no evaluation system was used to determine the degree of severity of ankle joint sprain (Mann et al. 2006). Therefore, injuries from non-serious clinical manifestations (ankle joint pain, no swelling, short-term walking inability) to serious sprain with ligament damage and persisting functional instability were included in the sprain data (AJI_PRE). This may also be one of the reasons why the percentage of sprains is high compared to other studies that included adult basketball players.

It is important to note that the teams included in our research belong to training centers that should not be compared to most regular school sports clubs. The generally high training doses and early sport specialization that occurs in these clubs may lead to more injuries in the long-term. In the present study, the majority of AJIs occurred in January (19.1\%). In February, the number of injuries decreased to almost half (10.6\%) and then subsequently, March to July displayed the lowest injury frequency (only $2.2 \%$ in a month). This injury pattern can be explained by the season's schedule, as most of the competitions end in April, with a hiatus from official training during the summer months. In August, camps resume, where $8.5 \%$ AJIs occurred. Then, the incidence of injuries increased with the start of the new season, from 
September to December, the injury rate averaged at $12.8 \%$ each month. These data agree with one study that found that most injuries of school aged basketball players occur in the winter season (44.4\% from December to March), with the most injuries in January (12.6\%) (Randazzo et al. 2010). Although not in children, other research showed that for male and female highschool basketball players, AJI frequency was greatest in-season, with fewer AJIs in the postseason and even fewer during the pre-season (Agel et al. 2007). The results of these studies coincide with the results of our work, as the most frequent injuries in the playing season, namely the winter season. An exception is the period from March to April, when the frequency of the injury was low.

\section{Conclusions}

In summary, 47 girls out of 91 reported that they had experienced at least one AJI, and almost half of the injured girls mentioned recurrence of injury. The most frequent injuries were reported on the right leg, and most players were injured in the winter, particularly in January. The balance exercises based on the elements of sensorimotor stimulation (10 to 15 minutes twice in a week) were included in basketball training of the BAL group, and a basketball player who underwent balance training had 3.97 times lower risk of AJI than those who did not participate in the additional balance training (Likelihood Ratio test $\mathrm{p}=0.043$ ), regardless of her age and previous injury status. Furthermore, a previously injured player had 4.33 times higher risk of an AJI in the 12 months study period than a player from the same group (BAL or CON) and of the same age who had not suffered an AJI before the experiment (Likelihood Ratio test $\mathrm{p}=0.038$ ). As a result, the girls from BAL suffered significantly fewer AJI in the 12-month study period $(\mathrm{p}<0.05)$ than the CON group that did not complete the additional barefoot balance training. This positive effect of balance exercises to decrease the rate AJI is especially important for coaches who coach young girls, a population that has shown to be quite susceptible to AJIs compared to other populations.

\section{Acknowledgments}

We sincerely thank to all the players who participated so willingly in the study and Mgr. Jan Vávra for help with the statistical processing of the results.

\section{Disclosure of interest}

The authors declare that they have no competing interest. 


\section{References}

1. AGEL, J., D. E. OLSON, R. DICK, E. A. ARENDT, S. W. MARSHALL \& R. S. SIKKA, 2007. Descriptive epidemiology of collegiate women's basketball injuries: National Collegiate Athletic Association Injury Surveillance System, 1988-1989 through 20032004. J Athl Train. 42, 202-210.

2. BOROWSKI, L. A., E. E. YARD, S. K. FIELDS \& R. D. COMSTOCK, 2008. The epidemiology of US high school basketball injuries, 2005-2007. Am J Sports Med. 36, 232835.

3. COLLIANDER, E., E. ERIKSSON, M. HERKEL \& P. SKOLD, 1986. Injuries in Swedish elite basketball. Orthopedics, 9, 225-7.

4. CUMPS, E., E. VERHAGEN \& R. MEEUSEN, 2007. Prospective epidemiological study of basketball injuries during one competitive season: ankle sprains and overuse knee injuries. J Sports Sci Med, 6, 204-11.

5. DEITCH, J. R., C. STARKEY, S. L. WALTERS \& J. B. MOSELEY, 2006. Injury risk in professional basketball players: a comparison of Women's National Basketball Association and National Basketball Association athletes. Am J Sports Med. 34, 1077-83.

6. DICK, R., J. HERTEL, J. AGEL, J. GROSSMAN \& S. W. MARSHALL, 2007. Descriptive epidemiology of collegiate men's basketball injuries: National Collegiate Athletic Association Injury Surveillance System, 1988-1989 through 2003-2004. Journal of athletic training. 42, 194.

7. DOHERTY, C., E. DELAhunT, B. CAUlfiEld, J. HERTEL, J. RYAN \& C. BLEAKLEY, 2014. The incidence and prevalence of ankle sprain injury: a systematic review and meta-analysis of prospective epidemiological studies. Sports Med. 44, 123-40.

8. DRAKOS, M. C., B. DOMB, C. STARKEY, L. CALLAHAN \& A. A. ALLEN, 2010. Injury in the national basketball association: a 17-year overview. Sports Health. 2, 284-90.

9. FARZAMI, A. \& M. ANBARIAN, 2020. The effects of fatigue on plantar pressure and balance in adolescent volleyball players with and without history of unilateral ankle injury. Science \& Sports. 35, 29-36.

10. FONG, D. T., Y. HONG, L. K. CHAN, P. S. YUNG \& K. M. CHAN, 2007. A systematic review on ankle injury and ankle sprain in sports. Sports Med. 37, 73-94.

11. FRANK, C., P. PAGE \& R. LARDNER, 2009. Assessment and treatment of muscle imbalance: the Janda approach, Human kinetics. 
12. FREEMAN, M., M. DEAN \& I. HANHAM, 1965. The etiology and prevention of functional instability of the foot. The Journal of bone and joint surgery. British volume. 47, 678-685.

13. GHRAM, A., M. DAMAK \& P. COSTA, 2017. Effect of acute contract-relax proprioceptive neuromuscular facilitation stretching on static balance in healthy men. Science \& Sports. 32, e1-e7.

14. HUNG, Y. J., 2015. Neuromuscular control and rehabilitation of the unstable ankle. World J Orthop. 6, 434-8.

15. KAMINSKI, T. W., J. HERTEL, N. AMENDOLA, C. L. DOCHERTY, M. G. DOLAN, J. T. HOPKINS, E. NUSSBAUM, W. POPPY, D. RICHIE \& A. NATIONAL ATHLETIC TRAINERS, 2013. National Athletic Trainers' Association position statement: conservative management and prevention of ankle sprains in athletes. J Athl Train. 48, 528-45.

16. KOFOTOLIS, N. \& E. KELLIS, 2007. Ankle sprain injuries: a 2-year prospective cohort study in female Greek professional basketball players. J Athl Train. 42, 388-94.

17. LEANDERSON, J., G. NEMETH \& E. ERIKSSON, 1993. Ankle injuries in basketball players. Knee Surg Sports Traumatol Arthrosc. 1, 200-2.

18. MANN, G., M. NYSKA, I. HETSRONI \& J. KARLSSON, 2006. Scoring systems for evaluating ankle function. Foot Ankle Clin. 11, 509-19.

19. MCGUINE, T. A. \& J. S. KEENE, 2006. The effect of a balance training program on the risk of ankle sprains in high school athletes. Am J Sports Med. 34, 1103-11.

20. MCKEON, P. O. \& J. HERTEL, 2008. Systematic review of postural control and lateral ankle instability, part I: can deficits be detected with instrumented testing. J Athl Train. 43, 293-304.

21. MELAM, G., A. ALHUSAINI, V. PERUMAL, S. BURAGADDA, A. ALBARRATI \& R. LOCHAB, 2018. Effect of weight-bearing overload using elastic tubing on balance and functional performance in athletes with chronic ankle instability. Science \& Sports. 33, e229-e236.

22. MESSINA, D. F., W. C. FARNEY \& J. C. DELEE, 1999. The incidence of injury in Texas high school basketball. A prospective study among male and female athletes. Am J Sports Med. 27, 294-9.

23. PAGE, P. 2006. Sensorimotor training: A "global" approach for balance training. Journal of Bodywork and Movement Therapies. 10, 77-84. 
24. POSTLE, K., D. PAK \& T. O. SMITH, 2012. Effectiveness of proprioceptive exercises for ankle ligament injury in adults: a systematic literature and meta-analysis. Man Ther. 17, 285-91.

25. RANDAZZO, C., N. G. NELSON \& L. B. MCKENZIE, 2010. Basketball-related injuries in school-aged children and adolescents in 1997-2007. Pediatrics. 126, 727-33.

26. ROHDE, J., 2012. Die sensomotorische Fazilitation (Kurzfußtechnik) nach Janda. Manuelle Medizin. 50, 183-188.

27. SANDLIN, M. I., C. E. TAGHAVI, T. P. CHARLTON \& R. D. FERKEL, 2017. Lateral Ankle Instability and Peroneal Tendon Pathology. Instr Course Lect. 66, 301-312.

28. SEFTON, J. M., C. YARAR, C. A. HICKS-LITTLE, J. W. BERRY \& M. L. CORDOVA, 2011. Six weeks of balance training improves sensorimotor function in individuals with chronic ankle instability. Journal of orthopaedic \& sports physical therapy, 41, 81-89.

29. SCHWEBEL, D. C. \& C. M. BREZAUSEK, 2014. Child development and pediatric sport and recreational injuries by age. J Athl Train. 49, 780-5.

30. SIERRA-GUZMAN, R., F. JIMENEZ-DIAZ, C. RAMIREZ, P. ESTEBAN \& J. ABIANVICEN, 2018. Whole-Body-Vibration Training and Balance in Recreational Athletes With Chronic Ankle Instability. J Athl Train. 53, 355-363.

31. TAYLOR, J. B., K. R. FORD, A. D. NGUYEN, L. N. TERRY \& E. J. HEGEDUS, 2015. Prevention of Lower Extremity Injuries in Basketball: A Systematic Review and MetaAnalysis. Sports Health. 7, 392-8.

32. VAN RIJN, R. M., A. G. VAN OS, R. M. BERNSEN, P. A. LUIJSTERBURG, B. W. KOES \& S. M. BIERMA-ZEINSTRA, 2008. What is the clinical course of acute ankle sprains? A systematic literature review. The American journal of medicine. 121, 324-331. e7.

33. VERHAGEN, E. A. \& K. BAY, 2010. Optimising ankle sprain prevention: a critical review and practical appraisal of the literature. Br J Sports Med. 44, 1082-8.

34. WATERMAN, B. R., B. D. OWENS, S. DAVEY, M. A. ZACCHILli \& P. J., JR. BELMONT, 2010. The epidemiology of ankle sprains in the United States. J Bone Joint Surg Am. 92, 2279-84.

35. ZECH, A., M. HUBSCHER, L. VOGT, W. BANZER, F. HANSEL \& K. PFEIFER, 2010. Balance training for neuromuscular control and performance enhancement: a systematic review. J Athl Train. 45, 392-403. 